\author{
M.S. Sagyndykova*, A.A. Imanbayeva, A.B. Lukmanov, G.G. Gassanova \\ Mangyshlak Experimental Botanical Garden, Aktau, Kazakhstan \\ *Corresponding author: m.sagyndykova@mail.ru
}

\title{
Resources of Rheum tataricum on the territory of Atyrau region
}

\begin{abstract}
Rheum tataricum is a valuable medicinal plant, the underground organs of which are used in folk medicine. This article is devoted to the study of the resources of Rheum tataricum in the previously unsearched Atyrau region. The article presents the results of field surveys of steppe and desert territories of the Atyrau region with the identification of typical communities with the participation of Rheum tataricum and the determination of industrially valuable thickets. According to the results of field work, 12 populations with the participation of the Tatar rhubarb were identified. 3 industrial sites with a total area of 4,006 hectares were identified. The yield of raw root materials ranged from 7,320 to $11,240 \mathrm{~kg} /$ hectare. The total operational reserve amounted to 36,592 tons, and the volume of possible collection of raw materials $-5,489$ tons. The obtained data indicates the possibility of industrial procurement of raw materials for the production of medicinal products.
\end{abstract}

Keywords: Rheum tataricum L., medicinal plant, resource, population, raw material, harvest.

\section{Introduction}

The study of the plant resources is a topical task of modernity. Generally, more than 5500 species of vascular plants grow on the territory of Republic of Kazakhstan [1], among them 1000-1200 species with proven and potential medicinal properties [2].

Rheum tataricum L. (Polygonaceae family) is perennial herbal plant with early circle of vegetation (from March till May) [3]. It is endemic to desert and steppe zones of Central Asia, grows on steppe slopes of lowland [4], forming thickets on highly compacted and saline gray-brown and gray-earth soils.

The roots of Rheum tataricum include polysaccharides, organic acids, phenols, carotene, vitamin C, tannins, antrachinones, amines, fat oils with different biological activity $[5,6,7]$. Accordingly, in folk medicine decoction of the roots and fruits of Rheum tataricum is used as a hemostatic agent for internal bleeding, as an anti-fever agent, as an astringent or laxative in gastric diseases, and ash - for scarring wounds. It is potential source for preparation, antioxidant, antitumor and P-vitamin activity $[8,9]$.

Earlier the plant resources of Rheum tataricum are studied in Southern and South-Eastern Kazakhstan $[4,10]$, bit investigation of raw material in the Western Kazakhstan is not conducted.

The purpose of present study is to determine spreading and resources of underground parts of Rheum tataricum at the territory of Atyrau region.

\section{Materials and methodology}

Object of the study is natural populations of Rheum tataricum at the territory of Atyrau region. The rhizome is vertical, strong, with old dark brown, young darkish vaginas; stems are usually 2-3, strong, furrowed, glabrous, hollow, branching from the middle, with branches deviating initially at an angle of $40^{\circ}$, and subsequently downward; leaves up to $35 \mathrm{~cm}$ long and $50 \mathrm{~cm}$ wide, rounded, heart-shaped at the base, with 3 main prominent veins, below, together with the petiole, covered with small trichomes, glabrous above; inflorescence spherical-panicle; flowers with 5 identical perianth lobes, $3 \mathrm{~mm}$ long, yellowish, with 3-5 brown veins; fruits $10-12 \mathrm{~mm}$ long and 8-10 $\mathrm{mm}$ wide; nuts are back-narrow-ovate, at the apex island. Dark brown, 1-1.5 mm wide, dark red-brown, heart-shaped below, tapering upward, with a vein along the edge of the wing; perianth lobes pressed against the fruit (Fig. 1).

Field surveys covering the steppe and desert territories of the region are conducted in May 2021 (Tab. 1). On natural populations, the species composition of communities was described, the main dominants and components are determined; the phases of phenological development of individual species, their living conditions, abundance (according to the Drude scale) were determined [11-13]. 


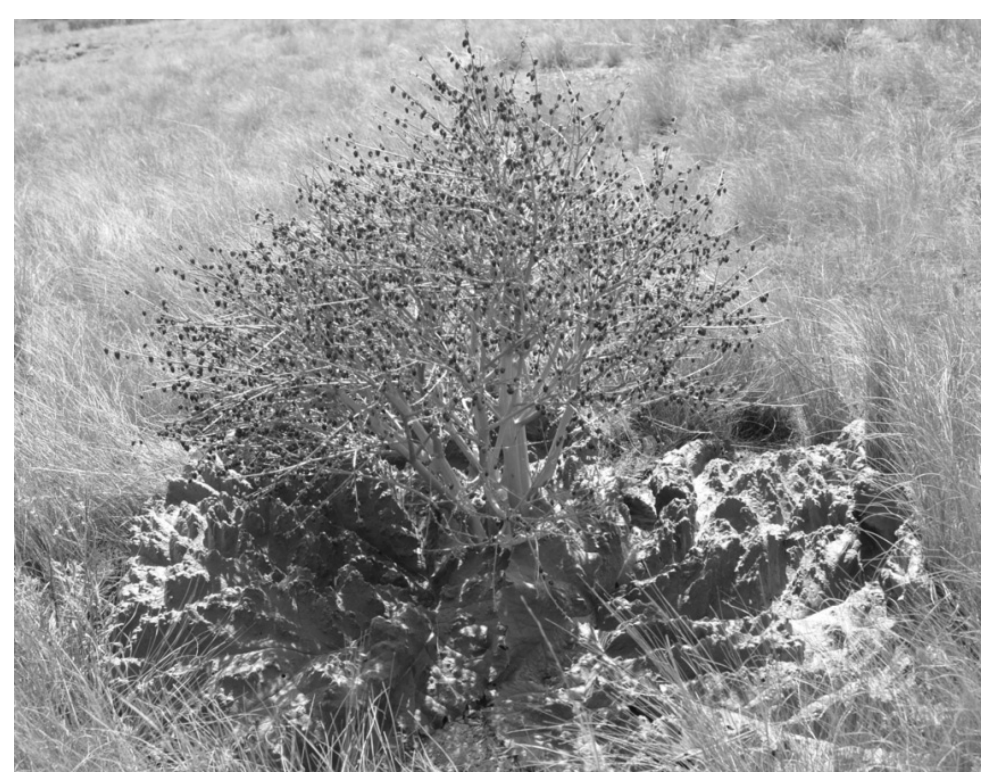

Figure 1. Exterior of Rheum tataricum, phase beginning of fructification

$\mathrm{Tab} l \mathrm{e} 1$

Survey points in the field of Atyrau region

\begin{tabular}{|c|c|c|c|}
\hline \multirow{2}{*}{ № } & \multirow{2}{*}{ Location } & \multicolumn{2}{|c|}{ GPS-coordinates } \\
\hline & & north latitude & east longitude \\
\hline 1 & $15 \mathrm{~km}$ on west from settlement Mahambet, clay plain & $47^{0} 45^{\prime} 243^{\prime \prime}$ & E $51^{0} 29^{\prime} 52^{\prime \prime}$ \\
\hline 2 & Surroundings of wintering Bolek, plain & $47^{0} 45^{\prime} 777^{\prime \prime}$ & $51^{0} 25^{\prime} 608^{\prime \prime}$ \\
\hline 3 & Northern coast of lake Inder, lowland & $48^{0} 31^{\prime} 987^{\prime}$ & $51^{0} 57^{\prime} 393^{\prime \prime}$ \\
\hline 4 & Western coast of lake Inder, lowland & $48^{0} 31^{\prime} 449^{\prime \prime}$ & $51^{0} 51^{\prime} 572^{\prime \prime}$ \\
\hline 5 & $30 \mathrm{~km}$ from lake Inder, plain & $48^{0} 30^{\prime} 564^{\prime \prime}$ & $52^{0} 2^{\prime} 733^{\prime \prime}$ \\
\hline 6 & Otpan Mount, lowland & $47^{0} 35^{\prime} 55^{\prime \prime}$ & $54^{0} 35^{\prime} 475^{\prime}$, \\
\hline 7 & Plain between settlements Sagyz and Myaly & $48^{0} 36^{\prime} 476^{\prime \prime}$ & $54^{0} 13^{\prime} 547^{\prime \prime}$ \\
\hline 8 & Hills Bekarys-Ata & $47^{0} 23^{\prime} 152^{\prime \prime}$ & $54^{0} 27^{\prime} 591^{\prime \prime}$ \\
\hline 9 & Plain between settlements Makat and Mukur & $47^{0} 43^{\prime} 305^{\prime \prime}$ & $53^{0} 33^{\prime} 216^{\prime \prime}$ \\
\hline 10 & Mount Imankara, plain & $47^{0} 19^{\prime} 496^{\prime \prime}$ & $54^{0} 22^{\prime} 121^{\prime \prime}$ \\
\hline 11 & $10 \mathrm{~km}$ on south from Mount Imankara, plain & $47^{0} 21^{\prime} 244^{\prime \prime}$ & $54^{0} 24^{\prime} 115^{\prime \prime}$ \\
\hline 12 & $20 \mathrm{~km}$ from settlement Dossor, steppe & $47^{0} 29^{\prime} 335^{\prime \prime}$ & $53^{0} 9^{\prime} 204^{\prime \prime}$ \\
\hline
\end{tabular}

For industrial-valuable thickets, the area, yield of roots is estimated, on the basis of which the production reserve and the volume of possible raw material collection are calculated [14, 15].

The obtained data were processed statistically [16].

\section{Results and discussion}

The species is an ephemeroid, in the spring it forms extensive thickets in the Atyrau region, ending its growing season by mid-late May. Populations with the participation of the species are described at the following points: plains between the settlements Sagyz, Makat, Mukur and Myaly; Bekarys-Ata hills, $15 \mathrm{~km}$ on the west of the settlements Mahambet; Bolek, near lake Inder with adjacent clay plains; Mount Imankara with environs, single thickets between the sandy massifs of Arakum and the settlement Kulsary.

Numerous points of discovery of communities with the participation of the Tatar rhubarb in the Atyrau region were noted. Rhubarb is part of the following communities (populations):

-Eremopyrum bonaepartis - Artemisia terra-albae - Herba xerophytica $15 \mathrm{~km}$ on west from settlement Mahambet and in surrounding of Lake Inder as a component;

-Poa bulbosa - Artemisia terrae-albae - Herba xerophytica in surroundings of wintering Bolek as a component;

-Rheum tataricum - Herba xerophytica on clay plain $30 \mathrm{~km}$ from Lake Inder as a dominant;

-Limonium suffruticosus - Atraphaxia spinosa in surrounding of Mount Imankara as a component; 
-Spiraea hypericifolia - Agropyron fragile - Herba xerophytica $30 \mathrm{~km}$ from Mount Imankara as a component;

-Rumex crispus - Herba xerophytica in hills Bekarys-Ata as a component;

-Artemisia terrae-albae - Ceratocarpus arenarius in surroundings of Mount Otpan as a component;

-Anabasis aphylla - Ceratocarpus arenarius in surroundings of Mount Otpan as a component;

-Medicago caerulea - Herba xerophytica on the plain between settlements Sagyz and Myaly as a component;

-Calamagrostis epigeios - Alhagi pseudoalhagi on the plain between settlements Makat and Mukur as a component;

-Poa bulbosa - Artemisia terrae-albae - Herba xerophytica in surrounding of Lake Inder as a component;

-Artemisia terrae-albae - Tamarix elongata on a plain $20 \mathrm{~km}$ from settlement Dossor.

Rheum tataricum forms significant thickets on a plain $30 \mathrm{~km}$ from Lake Inder as part of a diverserhubarb community. Longevity in the community is not expressed. Species composition not rich - 12-14 species, including Artemisia terrae-albae with abundance sol, Eremopyrum triticeum with abundance sol, Lepidium perfoliatum with abundance sol, Descurainia sophia with abundance sp-sol, Agropyron desertorum with abundance sol and other.

The territory is a plain with a slight difference in heights. Soils are dark brown, loamy. The mode of nutrition is atmospheric precipitation, groundwater; natural runoff of precipitation in decrease. The total projective cover in the community was 55-60\%. The territory is actively used for grazing livestock, as a result of overpopulation it causes a violation of the vegetation cover, expressed by $15-20 \%$. Rhubarb forms an abundance of cop2-cop3; the vitality of the species is $2-3$ points.

The area of community thickets with the participation of Rheum tataricum is 1316 hectares with a total area of 2400 hectares (Tab. 2). The stock density was from 1.0 to $2.2 \mathrm{specimen} / \mathrm{m}^{2}$. The yield was 11,240 $\mathrm{kg} / \mathrm{ha}$ based on dry weight. The exploitation reserve is estimated at 14,792 tons, the volume of possible annual harvests of air-dry raw materials is 2,219 tons.

Table 2

Raw materials resources of Rheum tataricum on the territory of Atyrau region (on air-dry weight)

\begin{tabular}{|l|c|c|c|c|c|}
\hline \multicolumn{1}{|c|}{ Place of thicket } & \multicolumn{2}{|c|}{ Square, ha } & $\begin{array}{c}\text { Crop yield, } \\
\mathrm{kg} / \mathrm{ha}\end{array}$ & $\begin{array}{c}\text { Exploitation } \\
\text { reserve, ton }\end{array}$ & $\begin{array}{c}\text { Volume of possible } \\
\text { annual harvests, ton }\end{array}$ \\
\cline { 2 - 5 } & total & With studied species & 11,240 & 14,792 & 2,219 \\
\hline $\begin{array}{l}\text { Clay plain in 30 km from } \\
\text { Lake Inder }\end{array}$ & 2,400 & 1,316 & 9,540 & 9,063 & 1,360 \\
\hline $\begin{array}{l}\text { The plain between settle- } \\
\text { ments Makat and Mukur }\end{array}$ & 1,540 & 0,950 & 7,320 & 12,737 & 1,910 \\
\hline $\begin{array}{l}\text { The plain in surrounding of } \\
\text { settlement Mahambet }\end{array}$ & 3,120 & 1,740 & & 36,592 & 5,489 \\
\hline Total: & 7,060 & 4,006 & & \\
\hline
\end{tabular}

The second industrial site is marked on the clay plain between the villages Makat and Mukur. The soils are brown, clay; the total projective cover is $50-55 \%$; humidity is provided by precipitation and natural runoff. The species composition of the community is represented by 19-21 species, of which Alhagi pseudoalhagi dominant species with abundance cop1, Calamagrostis epigeios with abundance cop-sp, Artemisia terrae-albae with abundance - sp-cop, Rheum tataricum - sp-cop, Poa bulbosa with abundance spsol, Lepidium perfoliatum with abundance sol, Descurainia sophia with abundance sol, Peganum harmala with abundance sol and other.

Plants form 2 tiers of vegetation: the upper (up to 80-90 cm high) consists of Calamagrostis epigeios, Artemisia scopaeformis, Alhagi pseudoalhagi; the lower (up to 30-40 cm high) is represented by low grasses, among which Rheum tataricum, Lepidium perfoliatum, Tanacetum santolina, Poa bulnbosa, Artemisia terrae-albae, Peganum harmala and others. The territory is used for grazing livestock, the degree of disturbance of the vegetation cover is $20-25 \%$.

The total area of the thicket was 16540 hectares, of which 950 hectares are directly occupied by the Rheum tataricum (Tab. 2). The yield was $9,540 \mathrm{~kg} / \mathrm{hectare}$. The exploitation reserve is estimated at 9,063 tons, the volume of possible collection of raw materials is 1,360 tons. 
A third industrial overgrowth was identified in the vicinity of settlement Mahambet. The territory is represented by a clay plain with an alternation of brown and light chestnut soils. The total projective cover was $30-40 \%$, vegetation degradation was noted by $20-25 \%$ due to grazing.

20-25 species are identified in the vegetation cover, of which dominant species - Artemisia terraalbae with abundant - cop1-cop2, co-dominant - Eremopyrum bonaepartis with abundant - cop1. Other members of vegetation are: Rheum tataricum - sp, Lepidium perfoliatum with abundance sol, Peganum harmala with abundance sol, Ferula nuda - sol, Camphorosma lessingii — sol, Lappula spinoseras — sol, Sisimbrium loeselii — un-sol and others.

Tiers in this area are not expressed. The area of the thicket amounted to 3120 hectares, of which 1740 hectares are occupied by Rheum tataricum. Yield is estimated at $7320 \mathrm{~kg} /$ hectare. The operational reserve was estimated at 12737 tons, the volume of possible collection of raw materials is 1910 tons.

The total area of thickets with the participation of Rheum tataricum amounted to 4,006 hectares, the total exploitation reserve is determined in 36,592 tons, the volume of possible collection of raw materials 5,489 tons.

The obtained data show sufficient potential of the given medicinal plant for organization of industrial collection for production of phytopreparations based on its raw material.

\section{Conclusion}

Thus, on the territory of the Atyrau region, 12 types of communities were identified with the participation of Rheum tataricum, confined to the steppe and desert sections of the region.

Three thickets have industrial potential for harvesting raw materials of underground organs of this type. It was determined that the total area of industrial thickets was 4,006 hectares, the total exploitation reserve is determined in 36,592 tons, the volume of possible collection of raw materials $-5,489$ tons.

The results can be used to organize raw materials of a medicinal plant.

\section{Acknowledgement}

The article is prepared accordance with Grant Project of Science Committee of the Ministry of Education and Science (AP092600081 «Study of biological features, ranges, raw materials of medicinal plants of Atyrau region and assessment of their practical use»).

\section{References}

1 Флора Казахстана. — Т. 1-9. - Алма-Ата: Наука, 1956-1966.

2 Грудзинская Л.М. Аннотированный список лекарственных растений Казахстана / Л.М. Грудзинская, Н.Г. Гемеджиева, Н.В. Нелина, Ж.Ж. Каржаубекова. - Алматы, 2014. — С. 111-115.

3 Грудзинская Л.М. Растения пустынных территорий Прибалхашья в коллекциях Главного ботанического сада / Л.М. Грудзинская // Успехи современного естествознания. — 2015. — № 5. - С. 160-166.

4 Кашкарова Н.Ф. Сырьевые запасы ревеня татарского в Прибалхашье / Н.Ф. Кашгарова // Тр. Ин-та ботаники АН КазССР. - 1965. - Т. 21. - С. 40-73.

5 Чумбалов Т.К Флавоноиды Rheum tataricum L. / Т.К. Чумбалов, Г.М. Нургалиева // Химия природных соединений. - 1967. - № 5. - С. 345-346.

6 Гемеджиева Н.Г. К ботаническим и фитохимическим исследованиям Rheum tataricum L. из Южного Прибалхашья / Н.Г. Гемеджиева, Н.В. Курбатова, Р.А. Музычкина, Д.Ю. Корулькин // Вестн. Караганд. ун-та. Сер. Биология. Медицина. География. - 2017. - № 2 (86). - С. 40-47.

7 Каржаубекова Ж.Ж. Элементный, амино- и жирнокислотный состав Rheum tataricum L. из Южного Прибалхашья / Ж.Ж. Каржаубекова, Н.Г. Гемеджиева // Вестн. Караганд. ун-та. Сер. Химия. — 2016. — № 4 (84). — С. 21-26.

8 Растительные ресурсы СССР: Цветковые растения, их химический состав, использование. - Л., 1984. - С. 275.

9 Жумашова Г.Т. Изучение некоторых технологических и некоторых фармакопейных характеристик лекарственного растительного сырья - корневищ ревеня татарского / Г.Т. Жумашова, Г.М. Саякова, Н.Г. Гемеджиева, Т.С. Бекежанова // Вестн. Казах. нац. мед. ун-та. - 2016. — № 1. - С. 531-535.

10 Гемеджиева Н.Г. Распространение и запасы Rheum tataricum L. в долине р. Или / Н.Г. Гемеджиева, К.Л. Мусаев, Ж.Ж. Каржаубекова, Ж.Т. Лесова, М.С. Рамазанова, В.А. Кириенко // Изв. НАН РК. Сер. биол. и мед. - 2016. - № 2 (314). - C. 72-79.

11 Быков Б.А. Введение в фитоценологию. - Алма-Ата: Изд-во АН КазССР, 1970. — 226 с.

12 Щербаков А.В. Полевое изучение флоры и гербаризация растений / А.В. Щербаков, А.В. Майоров. - М.: Изд-во МГУ, 2006. - 84 с.

13 Понятовская В.М. Учет обилия и характера размещения растений в сообществах / В.М. Понятовская // Тр. БИН. Cер. III. Геоботаника. — М.-Л., 1964. - Вып. 3. - С. 209-299. 
14 Крылова И.Л. Методические указания по изучению запасов дикорастущих лекарственных растений / И.Л. Крылова, А.И. Шретер. - М.: ВИЛАР, 1971. - 31 с.

15 Верник Р.С. Некоторые методы изучения популяций сырьевых растений при маршрутных обследованиях / Р.С. Верник // Сб. науч. тр. «Рациональное использование растительных ресурсов Казахстана». — Алма-Ата, 1986. C. 24-27.

16 Зайцев Г.Н. Методика биометрических расчетов / Г.Н. Зайцев. - М.: Наука, 1973. - 256 с.

\title{
М.С. Сагындыкова, А.А. Иманбаева, А.Б. Лукманов, Г.Г. Гасанова
}

\section{Rheum tataricum ресурстары Атырау облысы аумағында}

\begin{abstract}
Татар қызғалдағының жерасты органдары халық медицинасында қолданылатын құнды дәрілік өсімдік болып табылады. Бұл зерттеу бұрын зерттелмеген өңірдегі - Атырау облысындағы татар қызғалдағының ресурстарын зерттеуге арналған. Мақалада Атырау облысының далалық және шөлейт аумақтарындағы далалық зерттеу нәтижелері келтірілген. Далалық жұмыстардың қорытындысы бойынша 12 таралымы анықталды. Жалпы ауданы 4006 гектар болатын 3 өнеркәсіптік учаске табылды. Тамыр шикізатының өнімділігі гектарына 7320-ден 11240 кг-ға дейін болды. Жалпы пайдалану қоры 36592 тоннаны, ал шикізатты жинау мүмкіндігі 5489 тоннаны құрады. Алынған деректер дәрілік препараттарды өндіру үшін шикізатты өнеркәсіптік дайындау мүмкіндігін көрсетеді.
\end{abstract}

Кiлm сөздер: Rheum tataricum L., дәрілік өсімдік, ресурс, популяция, өсімдік шикізаты, өнім.

\author{
М.С. Сагындыкова, А.А. Иманбаева, А.Б. Лукманов, Г.Г. Гасанова
}

\section{Ресурсы Rheum tataricum на территории Атырауской области}

\begin{abstract}
Ревень татарский является ценным лекарственным растением, подземные органы которого находят применение в народной медицине. Данное исследование посвящено изучению ресурсов ревеня татарского в ранее не обследованном регионе - Атырауской области. В статье приведены результаты полевых обследований степных и пустынных территорий Атырауской области с выявлением типичных сообществ с участием ревеня татарского и определения промышленно-ценных зарослей. По итогам полевых работ выявлены 12 популяций с участием ревеня татарского. Определены 3 промышленных участка с совокупной площадью 4006 га. Урожайность сырья корней колебалась от 7320 до 11240 кг/га. Общий эксплуатационный запас составил 36592 т, а объем возможного сбора сырья - 5489 т. Полученные данные свидетельствуют о возможности промышленной заготовки сырья для производства лекарственных препаратов.
\end{abstract}

Ключевые слова: Rheum tataricum L., лекарственное растение, ресурс, популяция, растительное сырье, урожай.

\section{References}

1 (1956-1966). Flora Kazakhstana [Flora of Kazakhstan]. Vol. 1-9. Alma-Ata: Nauka [in Russian].

2 Grudzinskaya, L.N., Gemedzhieva, N.G., Nelina, N.V. \& Karzhaubekova, Zh.Zh. (2014). Annotirovannyi spisok lekarstvennykh rastenii Kazakhstana [Annotated list of medicinal plants of Kazakhstan]. Almaty [in Russian].

3 Grudzinskaya, L.N. (2015). Rasteniia pustynnykh territorii Pribalkhashia v kollektsiiakh Glavnogo botanicheskogo sada [Plants of desert territories of Balkhsh Region on collections of Main Botanical garden]. Uspekhi sovremennogo estestvoznaniia The successes of modern natural science, 5; 160-166 [in Russian].

4 Kashkarova, N.F. (1965). Syrevye zapasy revenia tatarskogo v Pribalkhashe [Raw material resources of Rheum tataricum in Balkhash region]. Trudy Instituta botaniki AN KazSSR - Proceeding of Institute of Botany of AS KazSSR, 21; 40-73 [in Russian].

5 Chumbalov, T.K. \& Nurgaliyeva, G. M. (1967). Flavonoidy Rheum tataricum L. [Flavonoids of Rheum tataricum L.]. Khimiia prirodnykh soedinenii - Chemistry of Natural Compounds, 5; 345-346 [in Russian].

6 Gemedzhieva, N.G., Kurbatova, N. V., Muzichkina, R. A \& Korulkin, D. Yu. (2017). K botanicheskim i fitokhimicheskim issledovaniiam Rheum tataricum L. iz Yuzhnogo Pribalhashia [At the botanical and phytochemical study of Rheum tataricum L. from the Southern Balkhash Region]. Vestnik Karagandinskogo universiteta. Seriia Biologiia. Meditsina. Geografiia - Bulletin of the Karaganda University, series biology, medicine, geography, 2 (86); 40-47 [in Russian].

7 Karzhaubekova, Zh.Zh. \& Gemedzhieva, N.G. (2016). Elementnyi, amino- i zhirnokislotnyi sostav Rheum tataricum L. iz Yuzhnogo Pribalkhashia [Elemental, amino and fatty acid composition of Rheum tataricum L. from the Southern Balkhash Region]. Vestnik Karagandinskogo universiteta. Seriia khimiia - Bulletin of the Karaganda University, series chemistry, 4 (84); $21-26$ [in Russian]. 
8 (1984). Rastitelnye resursy SSSR: tsvetkovye rasteniia, ikh khimicheskii sostav, ispolzovanie [Plant resources of USSR: flower plants, their chemical composition, using]. Leningrad [in Russian].

9 Zhumashova, G.T., Sayakova, G.M., Gemedzhieva, N.G. \& Bekezhanova, T.S. (2016). Izuchenie nekotorykh tekhnologicheskikh i nekotorykh farmakopeinykh kharakteristik lekarstvennogo rastitelnogo syria - kornevishch revenia tatarskogo [Study of some technological and some pharmacopoeia characteristics of medicinal plant raw materials - rhizomes of Tatar rhubarb]. Vestnik KazNMU - Bulletin of KazMU, 1; 531-535 [in Russian].

10 Gemedzhieva, N.G., Musayev, K. L., Karzhaubekova, Zh.Zh., Lesova, Zh. T., Ramasanova, M.S. \& Kirienko, V.A. (2016). Rasprostranenie i zapasy Rheum tataricum L. v doline r. Ili [Spreading and resources of Rheum tataricum L. in Ili valley]. Izvestiia NAN RK. Seriia biologiia i meditsina - Proceeding of NAS RK, series boil and med, № 2 (314); $72-79$ [in Russian]. sian].

11 Bykov, B.A. (1970). Vvedenie v fitotsenologiiu [Introduction into phytocenology]. Alma-Ata: Publ. AS KazSSR [in Rus-

12 Shcerbakov, A.V. \& Majorov, A.V. (2006). Polevoe izuchenie flory i gerbarizatsiia rastenii [Field study and plant herbarization]. Moscow: MSU [in Russian].

13 Ponyatovskaya, V.M. (1964). Uchet obiliia i kharaktera razmeshcheniia rastenii v soobshchestvakh [Account the abundance and nature of plant placement in communities]. Trudy BIN. Seriia III. Geobotanika - Works of Botanical Institute, Series III Geobotany. Moscow-Leningrad, 3; 209-299 [in Russian].

14 Krylova, I.L. \& Shreter, A.I. (1971). Metodicheskie ukazaniia po izucheniiu zapasov dikorastushchikh lekarstvennykh rastenii [Methodological recommendation on study of resources of wild medicinal plants]. Moscow: All-Russian Institute of Medicinal and Aromatic Plants [in Russian].

15 Vernik, R. S. (1986). Nekotorye metody izucheniia populiatsii syrevykh rastenii pri marshrutnykh obsledovaniiakh [Some methods of studying populations of raw plants in route surveys]. Sbornik nauchnykh trudov «Ratsionalnoe ispolzovanie rastitelnykh resursov Kazakhstana» - Book of abstracts The rational use of vegetative resources of Kazakhstan. Alma-Ata, 24-27 [in Russian]. sian].

16 Zajcev, G.N. (1973). Metodika biometricheskikh raschetov [Methodology of biometric account]. Moscow: Nauka [in Rus- 